\title{
Peningkatan Minat Dan Hasil Belajar Siswa Melalui Penerapan Model Pembelajaran Nht (Numbered Heads Together) Di Mts Pp. Nurul FalahTanjung Marulak Kec. Sei Kanan
}

\section{Increasing Student Interest and Learning Outcomes through the Application of the Nht (Numbered Heads Together) Learning Model at Mts Pp. Nurul Falah Tanjung Marulak Kec. Sei Kanan}

\author{
Siti Maryam Tanjung \\ Fakultas Tarbiyah, Institut Agama Islam Daar Al Uluum, Indonesia
}

Diterima :12 Agustus 2020; Disetujui : 24 Agustus 2020; Dipublish : 29 Agustus 2020

*Corresponding author: E-mail: smaryamtj@gmail.com

\begin{abstract}
Abstrak
Penelitian ini menggunakan model pembelajaran NHT (Numbered Head Together) Subjek penelitian adalah 30 siswa kelas VIII MTs, terdiri dari 13 laki-laki dan 17 perempuan. Jenis tindakan dalam penelitian ini berdasarkan siklus yaitu siklus I dan II, setiap siklus dilakukan sekali pertemuan dan diakhir pertemuan diadakan tes untuk mengetahui minat dan hasil belajar siswa. Tujuan yang hendak dicapai adalah untuk mengetahui: (1) Minat dan hasil belajar SKI siswa sebelum menggunakan model pembelajaran NHT (Numbered Head Together dan (2) Minat dan hasil belajar SKI siswa melalui penerapan model pembelajaran NHT (Numbered Head Together) materi perkembangan Islam pada masa Dinasti Ayyubiyah. Hasil penelitian Tindakan kelas ini dapat dikemukakan bahwa minat belajar pra tindakan dari 30 siswa minat belajar yang tinggi terdapat 5 siswa $(16,7 \%)$, Minat belajar yang kategori sedang sebanyak 8 siswa (26,7\%) dan 17 siswa (56,7\%) memiliki minat belajar rendah. pada siklus I minat belajar yang tinggi 12 atau 40\% siswa, minat belajar yang Sedang sebanyak 7 atau 23,3\% siswa, dan 11 atau $36,7 \%$ siswa memiliki minat rendah, Sedangkan pada siklus II minat belajar siswa terjadi peningkatan yang signifikan, 24 atau 80\% siswa memiliki minat yang tinggi, kategori sedang 6 atau 20\% siswa. Sedangkan hasil belajar pada pra tindakan dari 30 siswa 20 atau $66,7 \%$ siswa belum mencapai batas ketuntasan dan hanya 10 atau 33,3\% siswa. Siklus I 18 atau 60\% siswa yang tuntas, 12 atau 40\% siswa yang tidak tuntas. Sedangkan siklus II 26 atau $86,7 \%$ siswa yang tuntas, $13,3 \%$ siswa yang tidak tuntas.

Kata Kunci: Minat; Hasil Belajar; Model Pembelajaran NHT (Numbered Heads Together)
\end{abstract}

\begin{abstract}
This research uses the NHT (Numbered Head Together) learning model. The research subjects are 30 students of class VIII MTs, consisting of 13 boys and 17 girls. The type of action in this study is based on cycles, namely cycle I and II, each cycle is carried out once and at the end of the meeting) a test was held to determine student interest and learning outcomes. The objectives to be achieved are to find out: (1) Students' interest and learning outcomes for SKI before using the NHT (Numbered Head Together) learning model and (2) Student's interest and learning outcomes through the application of the NHT (Numbered Head Together) learning model of Islamic development material in during the Ayyubid Dynasty. The results of this classroom action research can be argued that the pre-action learning interest of 30 students with high interest in learning there were 5 students (16.7\%), 8 students (26.7\%) and 17 students (56.7\%) $\%)$ have low interest in learning. in cycle I high interest in learning 12 or $40 \%$ of students, moderate interest in learning was 7 or $23.3 \%$ of students, and 11 or $36.7 \%$ of students had low interest, while in cycle II student interest in learning occurred a significant increase, 24 or $80 \%$ of students have high interest, 6 or 20\% of students in moderate category. While the learning outcomes in the pre-action of 20 students or $66.7 \%$ of students have not reached the completeness limit and only 10 or $33.3 \%$ of students. Cycle I 18 or $60 \%$ of students who complete, or 12 or $40 \%$ of students who do not. While the second cycle is 26 or $86.7 \%$ of students who complete, $13.3 \%$ of students who do not. Keywords: Interest; Learning Outcomes; NHT (Numbered Heads Together) Learning Model
\end{abstract}

Rekomendasi mensitasi :

Tanjung, S. M. 2020. Peningkatan Minat Dan Hasil Belajar Siswa Melalui Penerapan Model Pembelajaran Nht (Numbered Heads Together) Di Mts Pp. Nurul Falah Tanjung Marulak Kec. Sei Kanan Jurnal Penelitian Pendidikan, Psikologi dan Kesehatan (J-P3K), 1 (2): 163-173. 


\section{PENDAHULUAN}

Pendidikan merupakn keputahn yang paling penting bagi kehidupan manusia. Dengan pendidikan manusia dapat mengembangkan atau memahami dirinya, pendidikan juga merupakan syarat yang harus dimiliki setiap manusia untuk menjalani kehidupan diera globalisasi. Perubahan dan Perkembangan pendidikan adalah hal yang seharusnya terjadi sejalan dengan perubahan budaya kehidupan. Perubahan dalam arti harus terus menerus dilakukan sebagai antispasi kepentingan dimasa depan.

Kegiatan belajar mengajar merupakan kegiatan yang mengandung serangkaian perbuatan guru dan siswa atas dasar hubungan timbal balik yang berlangsung secara edukatif untuk mencapai tujuan tertentu. Dalam kegiatan belajar mengajar terjadi transfer ilmu pengetahuan, sikap dan nilai-nilai, serta keterampilan dari guru kepada siswanya. Karena itu belajar mengajar merupakan interaksi antara dua unsur manusiawi, yaitu siswa sebagai pihak yang belajar dan guru sebagai pihak yang mengajar dalam rangka mencapai tujuan pengajaran.

Salah satu hal penting yang harus dimiliki siswa untuk mencapai hasil belajar yang maksimal adalah minat belajar. Minat besar pengaruhnya terhadap belajar karena bila bahan pelajaran yang dipelajari tidak sesuai dengan minat siswa, siswa tidak akan belajar dengan sebaik-baiknya karena tidak ada daya tarik baginya".

Usaha untuk membangkitkan minat belajar siswa erat hubungannya dengan kebutuhan siswa, pengetahuannya tentang kemajuan yang diperolehnya dalam kegiatan belajar dan adanya cita- cita (aspirasi). Untuk itu berbagai upaya perlu dilakukan untuk meningkatkan minat belajar siswa dalam pembelajaran SKI, dimana pembelajaran tersebut mempunyai peranan penting dalam kehidupan, akan tetapi banyak siswa yang tidak tertarik dengan pelajaran SKI karena dianggap sulit dan melelahkan. Menyadari pentingnya pembelajaran SKI bagi kehidupan, maka hendaklah menjadi pelajaran yang menarik bagi siswa di antaranya dengan menggunakan metode mengajar yang bervariasi, menggunakan media yang menarik dalam kegiatan pembelajaran, mengaitkan kegiatan pembelajaran dengan kebutuhan siswa dan sebagainya.

Pada dasarnya, mempelajari Sejarah Kebudayaan Islam di MTs merupakan salah satu mata pelajaran yang menelaah tentang asal-usul, perkembangan, peranan kebudayaan/peradaban Islam dan para tokoh yang berprestasi dalam sejarah Islam di masa lampau, mulai dari perkembangan masyarakat Islam pada masa Nabi Muhammad Saw. dan Khulafaurrasyidin, Bani ummayah, Abbasiyah, Ayyubiyah sampai perkembangan Islam di Indonesia. Secara substansial mata pelajaran Sejarah Kebudayan Islam memiliki kontribusi dalam memberikan motivasi kepada peserta didik untuk mengenal, memahami, menghayati Sejarah Kebudayaan Islam, yang mengandung nilai-nilai kearifan yang dapat digunakan untuk melatih kecerdasan, membentuk sikap, watak dan kepribadian peserta didik.

Hasil wawancara dan observasi telah dilaksanakan peneliti dengan guru bidang studi SKI MTs PP. Nurul Falah Tanjung Marulak. Ibu Saybatul Aslamiyah, S.Pdi, 
menyatakan bahwa jumlah siswa kelas VIII adalah 30 siswa dimana 13 siswa laki-laki dan 17 siswa perempuan pada tahun ajaran baru, menyatakan bahwa materi pelajaran yang sulit adalah materi Perkembangan Islam Pada masa Dinasti Ayyubiyah, menyatakan juga bahwa hasil ulangan harian SKI kelas VIII materi perkembangan Islam pada masa Dinasti Ayyubiyah masih banyak siswa yang mendapat nilai dibawah KKM (Kriteria Ketuntasan Minimal) 70. Dari hasil ulangan harian SKI pokok bahasan Perkembangan Islam Pada masa Dinasti Ayyubiyah 20 orang siswa masih di bawah KKM, dan yang melebihi KKM sekolah berjumlah 10 orang siswa.

Permasalah yang selama ini terjadi adalah rendahnya minat siswa dalam mengikuti pembelajaran SKI sehingga hasil belajar siswa menurun. Salah satu penyebabnya adalah Penggunaan model pembelajaran kurang bervariasi, dimana metode yang dipakai guru masih menggunakan metode ceramah, kemudian siswa disuruh membaca dan bertanya kepada guru tentang materi pelajaran dan setelah itu diberi latihan, sehingga hal tersebut dapat mengakibatkan siswa merasa jenuh dan bosan, serta kurang terdorong untuk bertanya bahkan mengemukakan pendapat tentang materi pada saat mengikuti mata pelajaran. Apalagi jam pelajaran SKI diberikan pada jam ke-empat. Pada jam ini kondisi siswa cenderung menurun atau capek sehingga minat dalam mengikuti pelajaran menurun.

Meneurut penulis Salah satu model pembelajaran yang tepat untuk meningkatkan minat belajar siswa adalah dengan model pembelajaran NHT
(Numbered Head Together). Model pembelajaran NHT mengutamakan adanya kerja sama antara siswa dalam kelompok untuk mencapai tujuan pembelajaran dan memberikan kesempatan kepada siswa agar dapat terlibat aktif dalam kegiatan pembelajaran.

Berdasarkan uraian latar belakang masalah tersebut di atas peneliti ingin mengadakan penelitian tentang Peningkatan Minat Dan Hasil Belajar Siswa Melalui Penerapan Model Pembelajaran NHT (Numbered Heads Together) Mata pelajaran SKI Di Kelas VIII MTs PP. Nurul Falah Tanjung Marulak Kec. Sei Kanan.

\section{METODE PENELITIAN}

Penelitian yang dilakukan adalah Penelitian tindakan kelas (PTK), yaitu suatu kegiatan penelitian yang dilakukan di kelas. Tindakan tersebut di berikan oleh guru terhadap peserta didik. Tujuan utama dalam penelitian tindakan kelas adalah untuk memecahkan permasalahan nyata yang terjadi didalam kelas VIII MTs PP. Nurul Falah Tanjung Marulak kec. Sei Kanan. Penelitian ini dilaksanakan melalui dua siklus, dan beberapa langkah-langkah dalam setiap siklus adalah Perencanaan Tindakan, Pelaksanaan Tindakan, Observasi dan refleksi.

Tehnik pengumpulan data dengan cara Observasi, Tes, Angket. Tehnik Analisis data melaui Reduksi data, Penyajian data dan Penarikan kesimpulan

Dengan demikian dapat disimpulkan bahwa penelitian tindakan kelas adalah suatu proses pembelajaran yang menerapkan model pembelajaran NHT (Numbered Head Together) materi 
Perkembangan Islam masa Dinasti Ayyubiyah untuk mengatasi masalahmasalah yang ditemukan dalam proses pembelajaran sebelumnya dan sebagai salah satu upaya untuk meningkatkan kualitas proses serta hasil belajar.

\section{HASIL DAN PEMBAHASAN}

Minat dan Hasil Belajar SKI siswa Sebelum Penerapan Model Pembelajaran NHT (Numbered Head Together) di MTs PP. Nurul Falah.

Pada pertemuan awal siswa diberikan pre test yang bertujuan untuk mengetahui kemampuan awal siswa dan juga mengetahui gambaran-gambaran kesulitan yang dialami siswa dalam menyelesaikan soal-soal pada materi Perkembangan Islam masa Dinasti Ayyubiyah. Tes awal dilakukan untuk mengetahui apakah materi prasyarat atau wajib sudah dipahami oleh siswa.

Instrumen tes awal ini dibuat dalam bentuk angket dengan memberi tanda cek $(\sqrt{ })$ pada pernyataan sebanyak 20 item dan untuk tes dengan pilihan jawaban dan hasil belajar dibuat tes dalam bentuk soal pilihan berganda 15 item.

Dari hasil pre test yang telah dilaksanakan, maka terlihat nilai yang diperoleh siswa masih rendah dan belum mencapai nilai KKM,

Tabel 1. Rekapitulasi Minat Belajar Siswa Sebelum Tindakan

\begin{tabular}{cccc}
\hline No & Nilai siswa & $\begin{array}{c}\text { Jumlah } \\
\text { siswa }\end{array}$ & Persentase \\
\hline 1 & $33-39$ & 17 & $56,7 \%$ \\
2 & $40-49$ & 8 & $26,7 \%$ \\
3 & $50-60$ & 5 & $16,7 \%$ \\
& Jumlah & 30 & 100 \\
\hline
\end{tabular}

Nilai dari hasil angket minat belajar SKI siswa yang berisi tiga tingkat prefensi jawaban dengan pilihan jawaban Tinggi =
3, Sedang $=2$, dan Rendah $=1$, nilai tertinggi adalah tiga. Adapun jumlah soal minat 20 item dikalikan dengan nilai tertinggi sama dengan 60 . Kategori Interval pencapaian minat belajar siswa adalah 30-39 = Rendah, 40-49 = Sedang, dan 50-60 = Tinggi.

Dari hasil angket minat belajar SKI siswa sebelum penerapan model Pembelajaran NHT dapat dilihat pada tabel I di atas bahwa dari 30 siswa, hasil tes angket sebelum penerapan model pembelajran NHT (Numbered Head Togther) minat belajar yang tinggi terdapat 5 siswa $(16,7 \%)$, minat belajar yang kategori sedang sebanyak 8 siswa $(26,7 \%)$ dan 17 siswa $(56,7 \%)$ memiliki minat belajar rendah dalam belajar SKI di MTs PP. Nurul Falah Kec. Sei Kanan.

Tabel 2. Rekapitulasi Hasil Belajar Siswa Sebelum Tindakan

\begin{tabular}{cccc}
\hline No & Nilai siswa & $\begin{array}{c}\text { Jumlah } \\
\text { siswa }\end{array}$ & Persentase \\
\hline 1 & $33-69$ & 20 & $66,7 \%$ \\
2 & $\geq 70$ & 10 & $33,3 \%$ \\
& Jumlah & 30 & 100 \\
\hline
\end{tabular}

Dari data nilai pada tabel di atas terlihat bahwa 20 atau $66,7 \%$ siswa belum mencapai nilai 70, kemudian 10 atau $33,3 \%$ siswa sudah mencapai nilai $\geq$ 70.dapat disimpulkan bahwa dari 30 orang siswa yang mencapai nilai ketuntasan belajar sebanyak 10 orang $(33,3 \%)$. Data ini menunjukkan bahwa pencapaian presentase belum sesuai dengan tingkat KKM yang menyatakan bahwa ketuntasan harus $80 \%$ dari jumlah keseluruhan siswa. Nilai ini diperoleh dari hasil jawaban pre test siswa sebelum peneliti melaksanakan tindakan kelas.

Penerapan Model Pembelajaran NHT (Numbered Head Together) pada materi 
Perkembangan Islam masa Dinasti Ayyubiyah di kelas VIII MTs PP. Nurul Falah Kec. Sei Kanan

\section{SIKLUS I}

Pada siklus I siswa mulai diperkenalkan pembelajaran dengan menggunakan penerapan model pembelajaran NHT (Numbered Head Together), siklus I dilaksanakan dua kali pertemuan (4 x 40 menit) dikelas VIII MTs PP. Nurul Falah Tanjung Marulak Kec. Sei Kanan.

Guru atau peneliti menjelaskan atau mensosialisasikan di dalam kelas terlebih dahulu teori dan proses pembelajaran dengan menggunakan penerapan model pembelajaran NHT (Numbered Head Together) kepada siswa dan teknis pelaksanaannya, dan membagi siswa ke dalam kelompok belajar.

Tabel 3. Hasil Observasi Aktivitas Peneliti Di Kelas Pada Siklus I

\begin{tabular}{|c|c|c|c|c|c|}
\hline \multirow[t]{2}{*}{ No } & \multirow{2}{*}{$\begin{array}{l}\text { Kegiatan } \\
\text { Peneliti }\end{array}$} & \multicolumn{4}{|c|}{ NILAI } \\
\hline & & A & B & $\mathrm{C}$ & $\mathrm{D}$ \\
\hline 1 & Apersepsi & & $\sqrt{ }$ & & \\
\hline 2 & $\begin{array}{lr}\text { Membagi kelompok } \\
\text { dalam } & \text { model } \\
\text { pembelajaran } & \text { NHT } \\
\text { (Numbered } & \text { Head } \\
\text { Together) } & \end{array}$ & & & $\sqrt{ }$ & \\
\hline 3 & Penjelasan materi & & $\sqrt{ }$ & & \\
\hline 4 & Pengelolaan kelas & & & & $\sqrt{ }$ \\
\hline 5 & $\begin{array}{l}\text { Kemampuan dalam } \\
\text { membimbing } \\
\text { kelompok belajar } \\
\text { pada saat proses } \\
\text { pembelajaran }\end{array}$ & & & & $\sqrt{ }$ \\
\hline 6 & $\begin{array}{l}\text { Kemampuan } \\
\text { mengevaluasi minat } \\
\text { belajar }\end{array}$ & & & $\sqrt{ }$ & \\
\hline 7 & $\begin{array}{l}\text { Menyimpulkan } \\
\text { materi }\end{array}$ & & & $\sqrt{ }$ & \\
\hline 8 & $\begin{array}{l}\text { Menutup } \\
\text { pembelajaran }\end{array}$ & & $\sqrt{ }$ & & \\
\hline
\end{tabular}

Dari lembar observasi guru, pada tabel di atas dapat dijelaskan bahwa dari 8 indikator yang terdapat 3 poin memperoleh nilai baik sedangkan 3 indikator lagi memperoleh nilai c cukup, dan nilai kurang 2 indikator.

Dari hasil pengamatan observer tersebut dapat disimpulkan bahwa proses pengelolaan pembelajaran yang ditampilkan peneliti pada siklus I sudah cukup baik, namun dari segi tehnik perlu adanya perbaikan karena bagaimana pun pengelolaan pembelajaran sangat berpengaruh terhadap hasil belajar siswa.

Tabel. 4. Lembar Observasi Belajar Siswa Pada Siklus I

\begin{tabular}{|c|c|c|c|c|c|}
\hline \multirow[t]{2}{*}{ No } & \multirow{2}{*}{$\begin{array}{l}\text { Indikator } \\
\text { Diukur }\end{array}$} & \multicolumn{4}{|c|}{ NILAI } \\
\hline & & A & B & $\mathrm{C}$ & D \\
\hline 1 & $\begin{array}{ll}\text { Kehadiran } & \text { siswa } \\
\text { dalam KBM } & \end{array}$ & & $\sqrt{ }$ & & \\
\hline 2 & $\begin{array}{l}\text { Perhatian siswa } \\
\text { terhadap guru saat } \\
\text { memberikan } \\
\text { pembelajaran }\end{array}$ & & & $\sqrt{ }$ & \\
\hline 3 & $\begin{array}{l}\text { Keaktifan siswa } \\
\text { ketika } \\
\text { menyelesaikan } \\
\text { masalah/menemuka } \\
\text { n jawaban dari } \\
\text { masalah yang } \\
\text { diberikan }\end{array}$ & & & $\sqrt{ }$ & \\
\hline 4 & $\begin{array}{l}\text { keaktifan siswa } \\
\text { ketika berdiskusi }\end{array}$ & & & & $\sqrt{ }$ \\
\hline 5 & $\begin{array}{l}\text { Keberanian siswa } \\
\text { mengeluarkan } \\
\text { pendapat sendiri }\end{array}$ & & & & $\sqrt{ }$ \\
\hline 6 & $\begin{array}{l}\text { Keaktifan siswa } \\
\text { memperhatikan } \\
\text { jawaban/pendapat } \\
\text { teman }\end{array}$ & & $\sqrt{ }$ & & \\
\hline 7 & $\begin{array}{l}\text { Keaktifan siswa } \\
\text { menjawab } \\
\text { pertanyaan guru }\end{array}$ & & & $\sqrt{ }$ & \\
\hline 8 & $\begin{array}{l}\text { Kemampuan siswa } \\
\text { menarik kesimpulan } \\
\text { terhadap materi }\end{array}$ & & $\sqrt{ }$ & & \\
\hline
\end{tabular}

Berdasarkan lembar observasi aktifitas siswa ketika proses pembelajaran seperti tabel di atas dapat dikatakan 
pembelajaran pada siklus I ini berjalan dengan baik.

a) Hasil Pembelajaran Siklus I

- Minat dan Hasil Belajar

Dari pembelajaran yang telah dilaksanakan dan pengamatan observasi serta daftar angket minat yang diberikan terhadap siswa maka terlihat bahwa minat belajar siswa terjadi Hal ini dapat diketahui dari respon siswa yang positif ketika pembelajaran sedang berlangsung.

Dari hasil angket minat belajar SKI siswa pada materi Perkembangan Islam masa Dinasti Ayyubiyah sebelum penerapan model Pembelajaran NHT (Numbered Head Together) dapat diketahui bahwa dari 30 siswa, minat belajar yang tinggi terdapat 5 siswa $(16,7 \%)$, minat belajar yang kategori sedang sebanyak 8 siswa $(26,7 \%)$ dan 17 siswa $(56,7 \%)$ memiliki minat belajar rendah. Setelah diadakan pembelajaran dengen model pembelajaran NHT (Numbered Head Together) pada siklus I dapat diketahui bahwa dari 30 siswa

minat belajar yang tinggi 12 orang (40\%), minat belajar yang Sedang sebanyak 7 orang $(23,3 \%)$ dan 11 orang $(36,7 \%)$ memiliki minat rendah dalam belajar SKI di MTs PP. Nurul Falah Kec.Sei Kanan.

Indikator kedua yang dipergunakan untuk menunjukkan suksesnya proses belajar adalah hasil belajar. Hasil belajar SKI siswa pada materi Perkembangan Islam masa

Dinasti Ayyubiyah sebelum penerapan model Pembelajaran NHT (Numbered Head Together) atau pra tindakan dapat diketahui bahwa dari 30 siswa, 20 atau $66,7 \%$ siswa belum tuntas, sedangkan yang tuntas hanya 10 atau
$33,3 \%$ siswa. Setelah diterapkan model pembelajaran NHT (Numbered Head Together) pada siklus I dapat

Diketahui bahwa dari 30 siswa 12 atau $40 \%$ siswa belum tuntas, sedangkan yang tuntas 20 atau $60 \%$

pada siklus 1 menunjukkan bahwa pencapaian persentasi belum sesuai dengan tingkat KKM yang menyatakan bahwa ketuntasan harus $80 \%$ dari jumlah keseluruhan siswa, Nilai ini diperoleh dari hasil belajar siswa sesudah peneliti melaksanakan tindakan kelas.

Seperti pada siklus I siklus II juga terdiri dari satu kali pertemuan dan empat tahap yaitu: Perencanaan, Pelaksanaan, Pengamatan, Refleksi.

Aktivitas guru dalam melaksanakan pembelajaran dengan model pembelajran NHT (Numbered Head Together) pada materi Sejarah Perkembangan Islam masa Dinasti Ayyubiyah, pada saat yang sama juga peneliti diobservasi oleh guru bidang studi untuk memberikan pengamatan dan penyampaian yang jujur terhadap pelaksanaan pembelajaran, karena hal ini sangat berguna untuk perbaikanperbaikan tindakan yang akan dilakukan pada siklus berikutnya.

Dalam memberikan Nilai Skor yang dinilai yaitu A untuk Nilai Baik Sekali, B untuk Nilai Baik, C untuk Nilai Cukup dan D untuk Nilai Kurang Sekali. Adapun hasil observasi yang dilakukan guru bidang studi terhadap aktivitas mengajar guru pada siklus II sebagai berikut: 
Tabel. 5. Hasil Observasi Aktivitas Peneliti Di Kelas Pada Siklus II

\begin{tabular}{|c|c|c|c|c|c|}
\hline \multirow[t]{2}{*}{ No } & \multirow{2}{*}{$\begin{array}{l}\text { Kegiatan } \\
\text { Peneliti }\end{array}$} & \multicolumn{4}{|c|}{ NILAI } \\
\hline & & A & B & $\mathrm{C}$ & $\mathrm{D}$ \\
\hline 1 & Apersepsi & $\sqrt{ }$ & & & \\
\hline 2 & $\begin{array}{lr}\text { Membagi } & \text { kelompok } \\
\text { dalam } & \text { model } \\
\text { pembelajaran } & \text { NHT } \\
\text { (Numbered } & \text { Head } \\
\text { Together) } & \end{array}$ & & $\sqrt{ }$ & & \\
\hline 3 & Penjelasan materi & & $\sqrt{ }$ & & \\
\hline 4 & Pengelolaan kelas & $\sqrt{ }$ & & & \\
\hline 5 & $\begin{array}{l}\text { Kemampuan dalam } \\
\text { membimbing } \\
\text { kelompok belajar } \\
\text { pada saat proses } \\
\text { pembelajaran }\end{array}$ & & $\sqrt{ }$ & & \\
\hline 6 & $\begin{array}{l}\text { Kemampuan } \\
\text { mengevaluasi minat } \\
\text { belajar }\end{array}$ & & $\sqrt{ }$ & & \\
\hline 7 & $\begin{array}{l}\text { Menyimpulkan } \\
\text { materi }\end{array}$ & $\sqrt{ }$ & & & \\
\hline 8 & $\begin{array}{l}\text { Menutup } \\
\text { pembelajaran }\end{array}$ & $\sqrt{ }$ & & & \\
\hline
\end{tabular}

Tabel. 6. Hasil Observasi Aktivitas Belajar Siswa Pada Siklus II

\begin{tabular}{|c|c|c|c|c|c|}
\hline \multirow[t]{2}{*}{ No } & \multirow{2}{*}{$\begin{array}{l}\text { Indikator } \\
\text { Diukur }\end{array}$} & \multicolumn{4}{|c|}{ NILAI } \\
\hline & & A & B & $\mathrm{C}$ & D \\
\hline 1 & $\begin{array}{ll}\text { Kehadiran } & \text { siswa } \\
\text { dalam KBM } & \end{array}$ & $\sqrt{ }$ & & & \\
\hline 2 & $\begin{array}{l}\text { Perhatian siswa } \\
\text { terhadap guru saat } \\
\text { memberikan } \\
\text { pembelajaran }\end{array}$ & & $\sqrt{ }$ & & \\
\hline 3 & $\begin{array}{l}\text { Keaktifan siswa } \\
\text { ketika } \\
\text { menyelesaikan } \\
\text { masalah/menemuka } \\
\mathrm{n} \text { jawaban dari } \\
\text { masalah yang } \\
\text { diberikan }\end{array}$ & $\sqrt{ }$ & & & \\
\hline 4 & $\begin{array}{l}\text { keaktifan siswa } \\
\text { ketika berdiskusi }\end{array}$ & & $\sqrt{ }$ & & \\
\hline 5 & $\begin{array}{l}\text { Keberanian siswa } \\
\text { mengeluarkan } \\
\text { pendapat sendiri }\end{array}$ & & $\sqrt{ }$ & & \\
\hline 6 & $\begin{array}{l}\text { Keaktifan siswa } \\
\text { memperhatikan } \\
\text { jawaban/pendapat } \\
\text { teman }\end{array}$ & $\sqrt{ }$ & & & \\
\hline 7 & $\begin{array}{l}\text { Keaktifan siswa } \\
\text { menjawab } \\
\text { pertanyaan guru }\end{array}$ & & $\sqrt{ }$ & & \\
\hline 8 & $\begin{array}{l}\text { Kemampuan siswa } \\
\text { menarik kesimpulan } \\
\text { terhadap materi }\end{array}$ & & $\sqrt{ }$ & & \\
\hline
\end{tabular}

Berdasarkan lembar observasi aktifitas siswa ketika proses pembelajaran seperti tabel di atas dapat dikatakan pembelajaran pada siklus II ini berjalan dengan cukub baik.

\section{a)Hasil Pembelajaran Siklus II}

Seperti halnya pada siklus I, setelah pembelajaran pada siklus II ini dilaksanakan, maka ada dua hal yang ingin diketahui sesui dengan variabel penelitian yang ingin dicapai yaitu peningkatan minat dan hasil belajar siswa melalui model pembelajaran NHT (Numbered Head Together), dalam hal ini difokuskan pada materi perkembangan Islam masa Dinasti Ayyubiyah di kelas VII MTs PP, Nurul Falah Tanjung Marulak Kec. Sei Kanan.

\section{Minat Belajar dan Hasil Belajar}

Dari Pembelajaran yang telah dilaksanakan dan pengamatan observasi serta daftar angket minat yang diberikan terhadap siswa maka terlihatlah bahwa minat belajar siswa terjadi peningkatan. Hal ini dapat diketahui dari respon siswa yang positif ketika pembelajaran sedang berlangsung. Minat belajar siswa meningkat dikarenakan model pembelajaran yang dipakai tergolong masih baru bagi siswa yang selama ini hanya menggunakan metode ceramah dan tanya jawab, sedangkan yang peneliti terapkan adalah model pembelajaran NHT (Numbered Head Together), yakni siswa dibagi beberapa kelompok kemudian masing-masing siswa perkelompok diberikan nomor yang berbeda, sehingga dalam perkelompok siswa mengerjakan tugas yang berbeda namun sebelum dipersentasekan masing-masing siswa tiap kelompok menyatukan pendapat, tugas dan hasil yang diberikan kepada 
mereka. Sehingga model Pembelajaran yang peneliti terapkan merupakan sesuatu yang menarik perhatian siswa, sehingga dapat meningkatkan minat siswa untuk mengikuti pembelajaran

Dari hasil angket minat belajar SKI siswa setelah menggunakan model pembelajaran NHT (Numbered Head Together) padab siklus I dapat diketahui bahwa dari 30 siswa 12 atau $40 \%$ memiliki minat yang tinggi, 7 atau 23,3\% siswa memiliki minat yang Sedang dan 11 atau $36,7 \%$ memiliki minat rendah. Sedangkan pada siklus II setelah penerapan model pembelajaran NHT (Numbered Head Together) peningkatan minat mengalami signifikan, dari 30 siswa 26 atau $80 \%$ siswa memiliki minat yang tinggi sedangkan 6 atau $20 \%$ siswa memiliki minat yang sedang dalam belajar SKI di MTs PP. Nurul Falah Kec. Sei Kanan.

Indikator kedua yang dipergunakan untuk menunjukkan suksesnya proses belajar adalah hasil belajar. Hasil belajar SKI siswa pada materi Perkembangan Islam masa Dinasti Ayyubiyah setelah penerapan model pembelajaran NHT (Numbered Head Together) pada siklus I dapat diketahui bahwa dari 30 siswa 12 atau $40 \%$ siswa belum tuntas, sedangkan yang tuntas 20 atau $60 \%$. Sedangkan pada siklus II setelah penerapan model pembelajaran NHT (Numbered Head Together) dapat diketahui bahwa dari 30 siswa 4 atau 13,3\% siswa belum tuntas, 26 atau $86,7 \%$ siswa sudah tuntas.

Data ini menunjukkan bahwa pencapaian presentase terjadi peningkatan yang signifikan yaitu melampau tingkat KKM yang menyatakan bahwa ketuntasan harus $80 \%$ dari jumlah keseluruhan siswa dan Nilai ini diperoleh dari hasil belajar siswa sesudah melaksanakan penelitian tindakan kelas dengan menggunakan model pembelajaran NHT (Numbered Head Together). Dengan demikian dapat disimpulkan bahwa minat dan hasil belajar SKI siswa materi perkembangan Islam masa dinasti Ayyubiyah setelah penerapan model Pembelajaran NHT (Numbered Head Together) pada siklus II sudah memenuhi standar ketuntasan minimal (KKM) di MTs PP. Nurul Falah Kec. Sei Kanan.

Minat dan hasil Belajar SKI siswa Setelah Penerapan Model Pembelajaran NHT (Numbered Head Together) di MTs PP. Nurul Falah.

Siklus I

Setelah proses pembelajaran siklus I dilaksanakan maka peneliti memberikan tes untuk mengetahui sejauh mana peningkatan minat dan hasil belajar siswa. Dari hasil angket minat belajar SKI siswa selama proses pembelajaran berlangsung dengan menggunakan model pembelajaran NHT (Numbered Head Together) sebagaimana tabel di bawah ini:

\begin{tabular}{cccc}
\multicolumn{4}{c}{ Tabel. } \\
\hline No Hasil Angket & Nilai siswa & $\begin{array}{c}\text { Jumlah } \\
\text { siswa }\end{array}$ & Persentase \\
\hline 1 & $33-39$ & 11 & $36,7 \%$ \\
2 & $40-49$ & 7 & $23,3 \%$ \\
3 & $50-60$ & 12 & $40 \%$ \\
& Jumlah & 30 & 100 \\
\hline
\end{tabular}

Dari hasil angket minat belajar SKI siswa pada materi Perkembangan Islam masa Dinasti Ayyubiyah pada siklus I dapat dilihat pada tabel di atas bahwa dari 30 siswa, hasil tes angket minat belajar dengan model pembelajaran NHT (Numbered Head Together) pada siklus I bahwa minat belajar yang tinggi 12 orang 
(40 \%), minat belajar yang Sedang sebanyak 7 orang $(23,3 \%)$ dan 11 orang $(36,7 \%)$ memiliki minat rendah dalam belajar SKI di MTs PP. Nurul Falah Kec. Sei Kanan.

Indikator kedua yang dipergunakan untuk menunjukkan suksesnya proses belajar adalah hasil belajar SKI siswa setelah penerapan model pembelajaran NHT (Numbered Head Together). Adapun teknik pengambilan data adalah dengan melakukakn tes pada akhir pembelajaran pada siklus I dapat dilihat pada tabel di bawah ini:

Tabel. 8. Rekapitulasi Hasil Belajar Siswa Siklus I

\begin{tabular}{cccc}
\hline No & Nilai siswa & $\begin{array}{c}\text { Jumlah } \\
\text { siswa }\end{array}$ & Persentase \\
\hline 1 & $33-69$ & 12 & $40 \%$ \\
2 & $\geq 70$ & 18 & $60 \%$ \\
& Jumlah & 30 & 100 \\
\hline
\end{tabular}

Dari data nilai pada tabel di atas terlihat bahwa 12 atau $40 \%$ siswa belum mencapai nilai 70 , kemudian 20 atau $60 \%$ siswa sudah mencapai nilai $\geq 70$.

Dari tabel diatas dapat dijelaskan bahwa dari 30 orang siswa yang mencapai nilai ketuntasan belajar sebanyak 18 orang (60\%). Data ini menuinjukkan bahwa pencapaian presentase belum sesuai dengan tingkat KKM yang menyatakan bahwa ketuntasan harus $80 \%$ dari jumlah keseluruhan siswa. Nilai ini diambil dari hasil belajar siswa sesudah peneliti melaksanakan tindakan kelas.

\section{SIKLUS II}

Setelah pelaksanaan siklus II dilakukan maka peneliti mengadakan tes terhadap minat dan hasil belajar siswa terhadap materi Perkembangan Islam masa Dinasti Ayyubiyah. Dapat dilihat pada tabel di bawah ini:

Tabel.9.

\begin{tabular}{cccc}
\multicolumn{4}{c}{ Hasil Angket Minat Belajar Siswa Siklus II } \\
\hline No & Nilai siswa & $\begin{array}{c}\text { Jumlah } \\
\text { siswa }\end{array}$ & Persentase \\
\hline 1 & $33-39$ & - & - \\
2 & $40-49$ & 4 & $20 \%$ \\
3 & $50-60$ & 26 & $80 \%$ \\
& Jumlah & 30 & 100 \\
\hline
\end{tabular}

Dari hasil angket minat belajar SKI siswa setelah menggunakan model pembelajaran NHT (Numbered Head Together) dapat dilihat pada tabel di atas bahwa dari 30 siswa mengalami kenaikan signifikan. siswa yang memenuhi kriteria tuntas belajar sesuai dengan indikator yang ditetapkan adalah 26 atau (80 \%) siswa memiliki minat yang tinggi sedangkan 6 atau $20 \%$ siswa memiliki minat yang sedang. dalam belajar SKI di MTs PP. Nurul Falah Kec. Sei Kanan.

\begin{tabular}{cccc}
\multicolumn{4}{c}{ Tabel.10. Rekapitulasi Hasil Belajar Siswa Siklus II } \\
\hline No & Nilai siswa & $\begin{array}{c}\text { Jumlah } \\
\text { siswa }\end{array}$ & Persentase \\
\hline 1 & $67-69$ & 4 & $13,3 \%$ \\
2 & $\geq 70$ & 26 & $86,7 \%$ \\
& Jumlah & 30 & 100 \\
\hline
\end{tabular}

Dari data nilai pada tabel di atas terlihat bahwa 4 atau 13,3\% siswa belum mencapai nilai 70, kemudian 26 atau $86,7 \%$ siswa sudah mencapai nilai $\geq 70$. Dari 30 orang siswa yang mencapai nilai ketuntasan belajar sebanyak 26 orang atau $86,7 \%$. Data ini menunjukkan bahwa pencapaian presentase terjadi peningkatan peningkatan yang signifikan yaitu melampau tingkat KKM yang menyatakan bahwa ketuntasan harus $80 \%$ dari jumlah keseluruhan siswa.

Nilai ini diperoleh dari hasil belajar siswa sesudah melaksanakan penelitian tindakan kelas dengan menggunakan model pembelajaran NHT (Numbered Head Together). Dengan demikian dapat disimpulkan bahwa minat dan hasil 
belajar SKI siswa materi perkembangan Islam masa Dinasti Ayyubiyah setelah penerapan model Pembelajaran NHT (Numbered Head Together) pada siklus II sudah memenuhi standar ketuntasan minimal (KKM) di MTs PP. Nurul Falah Kec. Sei Kanan.

Karena indikator keberhasilan dalam penelitian telah tercapai berarti hipotesis tindakan telah tercapai yaitu:

1. Meningkatkan hasil belajar siswa kelas VIII MTs PP. Nurul Falah Tanjung Marulak kec. Sei Kanan pada mata pelajaran SKI pokok bahasan perkembangan Islam pada masa Dinasti Ayyubiyah penerapan model pembelajran NHT (Numbered Head Together) yang ditandai dengan tingkat ketuntasan belajar siswa mencapai $80 \%$ dan siswa mencapai nilai sesuai dengan KKM yaiu 70 atau lebih.

2. Meningkatnya minat siswa yang ditandai dengan keberanian siswa bertanya memberikan gagasan dan menjawab pertanyaan pada mata pelajaran SKI pokok bahasan perkembangan Islam pada masa Dinasti Ayyubiyah dapat dilihat dari hasil lembar angket minat dan observasi belajar siswa yang mencapai kriteria baik dan sangat baik.Bagian ini menyajikan hasil penelitian.

\section{SIMPULAN}

Berdasarkan analisis terhadap data hasil penelitan tindakan kelas dengan menggunakan model pembelajaran NHT (Numbered Head Together) dalam materi perkembangan Islam pada masa Dinasti Ayyubiyah di kelas VIII MTs PP. Nurul Falah Tanjung Marulak kec. Sei Kanan,
Setelah semua siklus selesai di laksanakan dengan menggunakan penerapan model pembelajaran NHT (Numbered Head Together) terlihat siswa lebih berminat dalam mengikuti pembelajaran, selain itu siswa lebih memahami materi pokok yang dipelajari dan hasil belajar siswa juga meningkat.

Setelah berakhirnya siklus II angka peningkatan minat dan hasil belajar SKI siswa materi perkembangan Islam masa dinasti Ayyubiyah meningkat. minat siswa nilai sedang 6 orang dan nilai Tinggi 26 orang, sedangkan hasil belajar yang tuntas 26 orang dan yang tidak tuntas 4 orang.

Melalui Penerapan model pembelajaran NHT (Numbered Head Together) dapat meningkatkan minat dan hasil belajar SKI siswa di MTs PP. Nurul Falah Kec. Sei Kanan.

\section{DAFTAR PUSTAKA}

Nur, W. \& Rasyidin A. 2013. Teori Belajar dan Pembelajaran. Medan: Perdana Publishing.

Darajat, Z. 20o1. Metodik Khusus Pengajaran Agama Islam. Jakarta: Bumi Aksara.

Dimyati \& Mujiono. 2009. Belajar dan Pembelajaran. Jakarta: Rineka Cipta.

Djaali. 2013. Psikologi Pendidikan. Jakarta: Bumi Aksara.

Djamarah, S. 2002. Psikologi Belajar, Jakarta: Rineka Cipta.

Mulyasa E. 2012. Praktik Penelitian Tindakan Kelas. Bandung: PT Remaja Rosdakarya.

Mulyasa, E. 2013. Pengembangan dan Implementasi Kurikulum 2013. Bandung: PT Remaja Rosdakarya,

Khadijah. 2013. Belajar dan Pembelajaran. Bandung: Citapustaka Media,

Kunandar. 2011. Guru Profesional impelementasi kurikulum Tingkat Satuan Pendidikan (KTSP) dan Sukses dalam Sertifikasi Guru. Jakarta: PT Raja Grafindo Persada,

Sardiman. 2005. Interaksi dan Motivasi Belajar Mengajar. Jakarta: Bumi Aksara

Shaleh, A. \& Muhbib A. 2004. Psikologi Suatu Pengantar dalam Perspektif Islam Jakarta: Prenada Media. 
Slameto. 2003. Belajar dan Faktor-faktor yang Mempengaruhinya. Jakarta: Rineka Cipta.

Sudjana, N. 2005. Penilaian hasil prose Belajar Mengajar,Bandung: Remaja Rosdakarya.

Sugiyono. 2011. Metode Penelitian Pendidikan Pendekatan Kuantitatif Kualitatip. Bandung: Alpabeta,

Supratiningrum, J. 2013. Sertegi Pembelajaran Teori dan Aflikasi. Jogjakarta: Ar Ruzz Media.

Suprijono, A. 2013. Cooperative Learning Teori \& Aflikasi Paikem. Yogyakarta: Pustaka Belajar.

Syah, M. 2004. Psikologi Pendidikan. Bandung: PT Remaja Rosdakarya.

Trianto. 2009. Mendesain Model Pembelajaran Inovatif-progresif. Jakarta: PT Kencan. 